TILTAI, 2018, 1, 95-114 ISSN 1392-3137 (Print), ISSN 2351-6569 (Online)

\title{
TARPDISCIPLININIS BENDRADARBIAVIMAS KURIANT VIENIJANČIĄ APLINKĄ
}

\author{
Nijolė Petronèlė Večkienė, Raimonda Brunevičiūtė, Julija Eidukevičiūtė \\ Vytauto Didžiojo universitetas, Lietuvos sveikatos mokslu universitetas
}

\begin{abstract}
Anotacija
Straipsnyje pristatomi Vytauto Didžiojo ir Lietuvos sveikatos mokslų universitetų dèstytojų tęstinių tyrimų rezultatai, pagrindžiama socialinių darbuotojų ir kitų profesionalų, dirbančių pagalbos žmogui srityje, bendradarbiavimo būtinybè, kuriant asmeni palaikančią socialinę aplinką, kuri straipsnyje suprantama kaip vienijanti aplinka (ang. unity environment). Teoriniai ir empiriniai socialiniu darbuotojų, sveikatos ir ugdymo specialistų bendradarbiavimo aspektai analizuojami, pabrèžiant konceptualią asmens iggalinimo nuostatą ir jos reikšmingumą senejjančioje, transformacijas išgyvenančioje visuomenèje. Remiantis tyrimų rezultatų interpretacija, aptariama tarpdisciplininio bendradarbiavimo raiška praktikoje, aktualizuojami profesionalų rengimo ir tęstinio mokymosi pokyčiai, pabréžiant pasirengimą dirbti tarpdisciplininejje komandoje. Pirmoje straipsnio dalyje aptariamos socialinès įtampos, jų raiška socialinio darbo ir sveikatos priežiūros praktikoje, atskleidžiant iššūkius žmogui - profesionalui ir klientui. Antroje dalyje išryškinama tarpdisciplininès komunikacijos, lemiančios ịgalinančios vienijančios aplinkos kūrimą, svarba socialinių įtampų kontekste, aptariama paramą teikiančio bendradarbiavimo raiška praktinèje veikloje. Trečioje dalyje analizuojami edukacinių tarpdisciplininio bendradarbiavimo prielaidų ir galimybių paieškos atvejai: reflektuojami medicinos ir socialinio darbo studijų programų analizès rezultatai; pristatomi studijų programų organizavimo pokyčiai, aptariama naujovių raiška studijų programose ir praktikoje. Apibendrinant ir sisteminant straipsnyje pateikiamą informaciją išvadų ir diskusijos dalyje aktualizuojama konsultavimo funkcijos raiška formaliojo ir neformaliojo mokymosi procese. Konsultavimas akcentuojamas kaip esminis ugdymo kaitos veiksnys, mokymosi visą gyvenimą strategija, lemianti nuostatos „centre - besimokantysis“ igyvendinimą tęstinio mokymosi procese. Formaliose profesionalų rengimo studijose tai gali užtikrinti dėstytojo tutoriaus pozicija, igalinanti studijavimo sistemiškumą; praktinejje veikloje - supervizorius, skatinantis reflektuoti profesinių santykių patirtį, taip tobulinant kompetenciją.
\end{abstract}

PAGRINDINIAI ŽODŽIAI: socialinis darbas, medicina, tarpdisciplininis bendradarbiavimas, vienijanti aplinka, konsultavimas.

\begin{abstract}
The article presents the results of continuing research performed at Vytautas Magnus University and Lithuanian University of Health Sciences which justifies the importance of collboration between social workers and other professionals working in the field of helping professions, creating a person's supportive social environment, which the article perceives as a unity environment. There are analyzed theoretical and empirical aspects of cooperation between social workers, health professionals and educators, emphasizing the conceptual attitude of personal empowerment and its significance in an aging, transforming society. The interpretation of the research results revealed, the interdisciplinary cooperation in practice is discussed, the changes of professional training and continuing education are highlighted, emphasizing readiness to work in an interdisciplinary team. In the first part of the article there are discussed social tensions, their expression in social work and healthcare practice, revealing the challenges for a person - a professional and a client. The second part of the article highlights the interdisciplinary communication, leading to the creation of enabling environment of unity, and the importance of social tensions in the context of supportive cooperation discussed re-
\end{abstract}


solution it's practice. In the third part there are analyzed cases for the conditions and possibilities of educational interdisciplinary cooperation: the results of the analysis of medical and social work study programs are reflected; introduced changes in the organization of study programs, discussed the expression of innovations in study programs and practice. There is emphasized counseling as a key factor in educational change in the implementation of a "learner center", a lifelong learning strategy in the process of continuing education. In formal professional training, this can ensure the position of the tutor, empowering systematic studying; in practice, supervisor encouraging reflection on professional experience, thus developing competence.

KEY WORDS: social work, medicine, interdiciplinary collaboration, unity environment, consulting.

DOI: http://dx.doi.org/10.15181/tbb.v78i1.1759

\section{Ivadas}

Vienas esminių XXI a. visuomenės bruožų yra multidisciplininis jos pobūdis, lemiantis būtinybę socialinę veiklą ir tyrimus grịsti konteksto analize, ịvertinant politinę, ekonominę, socialinę, kultūrinę dimensijas ir technologines sąlygas. Lisabonos strategijoje (2000) pabrěžiamas darnus augimas, socialinè sanglauda leidžia kalbėti apie veiklos ir tyrimų multikultūriškumo bei mokslų konvergencijos tendencijas. Tai šiuolaikinès visuomenès realybė, kurioje matome, kaip sunku susikalbėti paskirų sričių atstovams. Nepripažistant šios realybès vargiai tikètinas skirtingų sričių profesijų atstovų, dirbančių vienoje komandoje, susikalbėjimas.

Nesusikalbejjimas gali tapti pavojingu reiškiniu, kai visuomenès senejjimas, migracija, intensyviai besiplètojantis multikultūriškumas, informacinių technologijų ir rinkos ekonomikos „diktatas“ lemia įtampas visose žmogaus ir visuomenès gyvenimo srityse, didina socialinès poliarizacijos ir socialinès rizikos pavojų (Lorenz, 1998; Bell, 2003; Bauman, 2007; Urponen, 2017). Tokioje visuomenèje žmogui keliami vis nauji reikalavimai (Eidukevičiūtè, 2013; Stanišauskienė, Večkienè, 2000), lemiantys asmens ir aplinkos sąveikos kaitą, kintančius poreikius, ilgalaikes naujo tipo problemas.

Šiame kontekste akivaizdi pagalbos žmogui profesijų atsakomybè ir misija - inicijuoti bei palaikyti saugią, bendradarbiavimu grindžiamą socialinę aplinką, iggalinančią asmeni, šeimą, bendruomenę keisti savo situaciją. J. Tomlinsonas (2000), analizavęs globalizacijos poveikị kultūrai, tai vadina vienijančios aplinkos kūrimu (ang. unity environment). Sveikatos ir socialinio darbo specialistų bendradarbiavimo patirtis yra esminè, plètojant tokią socialinę aplinką. Tačiau tęstiniai tyrimai, kuriuos vykdome šioje srityje (2004-20016 m.), atskleidè bendradarbiavimo barjerus ir įtampas, kurie nulemti skirtingų profesinių kultūrų (Brunevičiūtè, Večkienė, 2011; Kavaliauskienė, 2005). Ilgalaikę istoriją turinti mediko profesija ir savo tapatumo ,ieškanti““ socialinio darbuotojo profesija turi skirtingą patirti ir skirtingą socialinị statusą. 
Kita vertus, saugios aplinkos kūrimo akcentavimas leidžia kalbèti apie socialinio darbo, kaip profesinès veiklos, išskirtinị vaidmenị. Socialiniam darbui dẻl jo empirinès prigimties būdingas interdiscipliniškumas, kurị M. Payne (2015) ịvardija socialinio darbo praktikos teorijos terminu. Socialinių darbuotojų veikla visada yra kompleksinè, veiklos rezultatas sunkiai „matomas“ ir prognozuojamas. Tai ne trumpalaikè vienkartinè intervencija, o tęstinis sąveikos procesas, vykstantis intensyviai kintančios aplinkos sąlygomis. Reflektuojant ir apibendrinant šio proceso patirtį, dalyvaujant supervizijos (profesinių santykių konsultavimo) procese, kuriamos naujos profesinès žinios. Profesinès veiklos bruožai, nulemti socialinio darbo ir supervizijos sąsajų, atskleidžia socialinio darbo reikšmingumą kuriant saugią, igalinančią vienijančia aplinką.

Socialinio darbo patirtis gali būti svarbi pirminès sveikatos priežiūros plètros kontekste, nes kartu su sparčia mokslo ir technologijų pažanga kinta požiūris i žmogaus sveikatos išsaugojimo ir stiprinimo problemas. Šiame kontekste kinta medikų veikla: šalia gydymo funkcijų vis dažniau akcentuojamos ir psichologinès bei socialinès sveikatos problemų sprendimo funkcijos. Didelę pirminès sveikatos priežiūros specialistų profesinès veiklos dalị sudaro probleminès situacijos, kurias norint išspręsti nepakanka tik ị biomediciną orientuotų kompetencijų (Kirikova, 2006). Svarbios tampa psichosocialinès, vadybinès, edukacinès kompetencijos (Brunevičiūtè ir kt., 2007). Keičiasi požiūris ị gydytojų profesiją, lemiantis jų profesinio rengimo ir nuolatinio kvalifikacijos tobulinimo kaitą. Viena esminių novacijų šiame kontekste yra problemų sprendimu pagrịsto mokymosi (ang. Problem based learning) igyvendinimas Lietuvos sveikatos mokslų universitete. Ši edukacinè naujovė leidžia kurti mokymosi aplinką, kuri skatina studentus ugdytis savarankiško mokymosi ir bendradarbiavimo gebejjimus.

Būtina atkreipti dèmesị ị tai, kad pagalbos žmogui profesionalų rengimo situacija Lietuvoje unikali, nes aukščiau minètos profesijos, taip pat ir ugdymas išgyvena paradigmų kaitą. Kaita sveikatos priežiūros sistemoje, kai biomedicininị požiūrị keičia biopsichosocialinis, sukuria tarpdiscipliniškumo prielaidas, jo praktinè raiška vis dar problemiška. Socialinès pagalbos deinstitucionalizavimas išryškina konceptualios ịgalinančio socialinio darbo nuostatos reikšmingumą ir skatina ieškoti jos ịgyvendinimo galimybių, tačiau būtina atkurti bendruomeninius ryšius. Siekiant ịgyvendinti mokymosi visą gyvenimą idẻją, reikia esminių pokyčių profesionalų ugdymo ir jų tęstinio kvalifikavimo procese.

Straipsnio tikslas: remiantis mokslinès literatūros ir empirinių tyrimų apžvalgos rezultatais, aptarti tarpdisciplininio bendradarbiavimo veiksnius, kurie lemia igalinančios vienijančios aplinkos kūrimą, išryškinti tarpdisciplininio bendradarbiavimo kompetencijų igijimo bei tobulinimo edukacines galimybes. 
Tikslui pasiekti išsikelti trys uždaviniai: 1) tarpdisciplininès komunikacijos aktualizavimas socialinių įtampų kontekste; 2) tarpdisciplininio bendradarbiavimo raiškos praktineje veikloje analizė; 3) mokymosi bendradarbiauti tarpdisciplininèje komandoje edukacinių galimybių paieška.

Straipsni sudaro trys dalys, atitinkančios išsikeltus uždavinius. Pirmoje straipsnio dalyje reflektuojamos socialinio darbo kaitos tendencijos, nulemtos socialinių ịtampų ir transformacijų. Antroje dalyje interpretuojami praktinių atvejų analizės rezultatai, leidžiantys kalbèti apie skirtingų žinių ir profesinių požiūrių sinergijos reikšmingumą, kuriant vienijančia aplinka, grindžiamą tarpdisciplininio bendradarbiavimo kompetencija. Trečioje dalyje aptariami edukacinių tarpdisciplininio bendradarbiavimo prielaidų ir galimybių paieškos atvejai: pristatomi medikų ir socialinių darbuotojų rengimo programų analizès rezultatai, apibūdinami esminiai tarpdisciplininio bendradarbiavimo aspektai ir iššūkiai, aptariami ugdymo paradigmų kaitos nulemti studijų proceso pokyčiai, pabrěžiamas problemų sprendimu pagrịsto mokymosi efektyvumas, igyvendinant „,entre - studentas “ nuostatą.

Straipsnyje laikomasi nuostatos, kad susitarimai dèl bendros vizijos, tikslo ir vertybiu lemia sėkmingą kiekvieno profesionalo veikimą komandoje, kartu ir tarpdisciplininį bendradarbiavimą, todèl susitarimas dèl specialistų ugdymo tikslų, suformuluotų remiantis bendromis vertybèmis, yra esminè bendradarbiavimo kompetencijos ugdymo sąlyga (Walter, Petr, 2000).

\section{Tarpdisciplininės komunikacijos aktualizavimas socialinių įtampų kontekste}

Interpretuojant tęstinių tyrimų rezultatus išryškèjo trys konceptualios sampratos, reikšmingos straipsnio tematikos prasme:

- multikultūriškumas (etnine ir profesinès kultūros prasme), kaip esminis šiuolaikinès visuomenès bruožas (Joint World Conference on Social Work and Social Development. Action and Impact, 2012);

- multiraštingumas, kaip reikalavimas XXI amžiaus žmogui, kuris veikdamas, pažindamas save ir pasaulį bei kurdamas ịprasmina save ir savo gyvenimą (Foucault, 2001);

- socialinis kapitalas, kaip svarbiausias vienijančios aplinkos kūrimo išteklius, kintančioje, senejjančioje visuomenèje, reikšmingai papildantis ekonominị ir žmogiškajị kapitalą (Coleman, 2005).

Multikultūriškumo požiūriu reikšmingos yra pasaulinès konferencijos „Socialinis darbas ir socialinis vystymasis: veiksmas ir poveikis“ jžvalgos, atskleidžiančios esmines problemas ir pagalbos žmogui pokyčių strategijas XXI amžiuje. Diskusijos konferencijoje aprẻpe šias problemines sritis: visų žmogaus teisių užti- 
krinimas; nepakankamas ekonomikos reguliavimas ir nepakankama socialinė atsakomybé; kultūros skirtingumai ir saviraiškos teisè, kai globalizacija standartizuoja ir marginalizuoja žmones, senąsias tautas ir kultūras; žmonės gyvena bendruomenėse, kurias ardo dominuojančios ekonominès, politinès ar socialinès jẻgos; žmonių sveikata ir gerovè nyksta dèl nelygybès ir nestabilios aplinkos.

Šiame probleminiame kontekste aptartos ir pagrịstos pagrindinès strateginès kryptys: 1) žmogaus teisių ir lygių galimybių igyvendinimas ịvairiose pasaulio šalyse, pabrēžiant aktyvaus senėjimo aktualumą; 2) darnus socialinis vystymasis, grindžiamas ekonominių, socialinių ir gamtos išteklių integravimu, atliepiant aplinkos pokyčius; 3) konkreti socialinè veikla bendruomenejje, užtikrinant socialinę apsaugą skurdą ir atskirtị patiriantiems asmenims globalinių socialinių transformacijų kontekste. Interpretuojant vienybès aplinkos diskusijas, galima teigti, kad kasdienès veiklos strategijų pagrindas turètų būti asmens dalyvavimo skatinimas ir palaikymas. Tai leistų mažinti institucionalizavimą, tik būtinas tarpdisciplininis bendradarbiavimas.

Svarbiausios asmens dalyvavimo sritys yra švietimas, šeimos gyvenimas, darbas, buitis, laisvalaikis. Kiekviena šiu sričių reikalauja tam tikro raštingumo. Multiraštingumo požiūriu svarbus M. Foucalt (2001) teorinis požiūris, kuriuo remiantis skiriamos trys tarpusavyje susijusios epistemos. M. Foucaltas jas ịvardija kaip žinias apie žmogų, socialinę aplinką, kalbas ir jų raišką. Jos užtikrina žmogaus dalyvavimą ir atsakomybę už savo veiklos padarinius bei atliepia XXI a. reikalavimus. Multiraštingumas siejamas su informacijos paieškos ir naudojimo gebejjimais; finansinėmis žiniomis ir planavimo bei apskaitos gebejjimais; internetiniu raštingumu, didejjant skirtumui tarp vartotojų ir ne vartotojų. Siekiant plètoti multiraštinguma, svarbi kasdienio informalaus mokymosi ir savišvietos kompetencija; gebejjimas perduoti ịvaizdžius, juos suprasti; interpretuoti patiriamas ar stebimas emocijas. Multiraštingumo tema išryškina ịtampas tarp asmens raštingumo ir paslaugas teikiančių darbuotojų bei organizacijos ar bendruomenès raštingumo. Šios itampos tampa esminès senejjimo ar negalès atveju.

Remiantis reabilitacijos srityje taikomu funkcionavimo modeliu išryškejja nuostata, kad senejjimas ir negalia nèra galimybių nebuvimas, įmanoma nepriklausomybe ir savarankiškumas, užtikrinus tam tinkamas sąlygas. Tokios sąlygos gali būti kuriamos, igyvendinant saugios fizinès ir psichosocialinės aplinkos arba vienijančios aplinkos idèją, kurią ịgyvendinant būtina pasitelkti skirtingų socialinių profesijų atstovus. Kitaip tariant, būtina tarpdisciplininè komanda. Jos nariai, siekdami bendro tikslo, keičiasi informacija, formuoja bendrą žinių bagažą ir bendradarbiaudami kaupia interdisciplininės veiklos patirtị, t. y. socialinị kapitala.

Vienijančios aplinkos kūrimo procese socialinio kapitalo samprata gali būti taikoma, formuojant minèto proceso strategini planą. Šiame kontekste akivaizdi 
profesionalų multiraštingumo, tarpdisciplininio bendradarbiavimo ir kritinio mintijimo būtinybè. Išvardytos kompetencijos laiduoja socialinio kapitalo kaupimo galimybių ir sąlygų užtikrinimą. Tačiau tyrimai atskleidè, kad socialiniai darbuotojai, sveikatos ir kiti specialistai kuria savo subjektyvumą, kuris gali padèti arba trukdyti tarpdisciplininiam bendradarbiavimui (Bogdanova, Večkienè, 2009; Brunevičiūtè, Večkienė ir kt., 2011; Večkienè, Eidukevičiūtė, 2016). Todèl kyla klausimas, ar pakankama socialinio kapitalo sampratos raiška praktikoje? Šiam klausimui skiriama antroji straipsnio dalis, kurioje aptarsime tarpdisciplininio bendradarbiavimo atvejus.

\section{Tarpdisciplininis bendradarbiavimas praktikoje}

Tarpdisciplininio bendradarbiavimo analizei, taikant socialinio, žmogiškojo, kultūros ir emocinio kapitalo sampratas, išryškèja interdiscipliniškumo turinys (Bourdieu, 1994; Coleman, 2005; Gendron, 2004). Šia prasme kultūros kapitalas yra esminis, formuojantis socialiniam kapitalui, nes skatina partnerystę, bendradarbiavimą ir tarpkultūinius ryšius. Tai savo ruožtu formuoja bendruomeninius ryšius, vietinius organizacijų tinklus, būtinus siekiant kompleksiškai spręsti psichosocialines problemas. Kultūros kapitalas svarbus ir tobulinant profesines studijas, rengiant specialistus, gebančius veiksmingai dalyvauti darnios plètros procese senejjančios visuomenès sąlygomis. Rečiau literatūroje aptinkama emocinio kapitalo samprata leidžia išryškinti asmeninès ir socialinès kompetencijos sąsajas, būtinas empatiškumo komandoje raiškai.

Profesionalų bendradarbiavimo trukdžiai. Vytauto Didžiojo ir Lietuvos sveikatos mokslų universitetų tęstinio tyrimo pirmajame etape (2003-2005 m.) atlikta serija žvalgomujų tyrimų, kuriais siekta ịvertinti tarpdisciplininių komandų, arba organizacijų, bendradarbiavimą, teikiant socialines paslaugas negalès, atskirties, skurdo situacijose. Apibendrinus tyrimo rezultatus (Večkienė, Eidukevičiūtè, 2004) išryškèjo keturi esminiai bendradarbiavimo barjerai. Pirma, skirtingų sričiu profesionalai nevienodai supranta pagalbą, jos prioritetus, jų veiklos modeliai ir konkretūs veiksmai gali būti visiškai skirtingi. Antra, valstybinių ir nevyriausybinių organizacijų atstovai pagalbos teikimą organizuoja skirtingai: pirmuoju atveju dominuoja institucionalizavimo kultūra, teikiant pagalbą laikomasi tam tikrų nusistovejjusių taisyklių, procedūrų, akcentuojamas rezultatas; antruoju - remiamasi iniciatyva, metodų paieška, daug dẻmesio skiriama procesui. Trečia, komandos veiklos koordinatorius dažniausia suprantamas kaip lyderis, kuriam priklauso atsakomybè ir „valdžia“. Ketvirta, kai pagalbą teikia tarpdisciplininè komanda arba institucijų tinklas, praktikoje beveik visada iškyla klausimas, kam priklauso pagal- 
bos proceso rezultatas? Kieno pastangos buvo svarbiausios ar lemiamos? Nesèkmès atveju - kas kaltas?

Tarpdisciplininė komanda praktikoje. Vytauto Didžiojo ir Lietuvos sveikatos mokslų universitetų pirmojo tyrimo etapo rezultatai paskatino pasidomèti konkrečiomis situacijomis, kur būtina tarpdisciplininè pagalba. Antrajame etape (2006-2010 m.) dèstytojai ir studentai atliko tyrimus, kurie patvirtino, kad tarpdisciplininio komandinio darbo gebèjimai turètų būti tikslingai ir nuosekliai plètojami. Tai leistų siekti integralumo socialinès pagalbos ir gydymo procese, jo rezultatyvumo (Večkienè ir kt., 2010). Siekiant geriau pažinti tarpdiscipliniškumo raiškos problemas ir galimybes, atliktas kokybinis tyrimas sveikatos priežiūros įstaigoje. Toliau straipsnyje, remiantis socialinio kapitalo teorija, aptariami šio tyrimo rezultatai (Bogdanova ir kt., 2009).

Kai socialinis darbuotojas dirba vienoje komandoje su sveikatos ir kitais specialistais ir siekia vieno tikslo, formuojasi tam tikri socialiniai santykiai. Remiantis J. S. Colemanu (2005), socialinio kapitalo teorijoje santykiai suprantami kaip komandinio darbo išteklius, o pati komanda - kaip socialinis kapitalas, kuris papildo žmogiškaji kapitalą ir padeda lengviau ir efektyviau veikti. Kitaip tariant, socialinis kapitalas sukuriamas tada, kai sparčiau vyksta žmonių tarpusavio santykių pokyčiai. Žmogiškujų išteklių ir socialinio kapitalo integracija svarbi siekiant darnaus veikimo, kartu tai padidina veiklos efektyvumą. Tarpdisciplininès informacijos kaupimas komandoje įmanomas tik socialinių santykių dèka. Tai svarbi socialinio kapitalo forma. Taigi santykiai yra vertingi dẻl jų kuriamos tarpdisciplininès informacijos, kuri lemia interdiscipliniškumą.

Gydytojai, socialiniai darbuotojai, slaugytojos, psichologai, užimtumo organizatoriai naudoja skirtingas žinias ir informaciją. Šių specialistų kompetencija byloja žmogiškujjų išteklių kokybę ir yra žmogiškojo kapitalo potencialas. Dalykinės komunikacijos procese, kai komandos nariai keičiasi individualiais informaciniais ištekliais, kuriamas socialinis kapitalas. Tyrimas atskleidè, kad medikams sunku suvokti socialinio darbuotojo veiklą kaip savarankišką, tačiau reikšmingą sveikatos priežiūros sričiai. Todèl komunikacijai tarpdisciplininèje komandoje būdingos ịtampos, trukdančios sukurti palaikančią vienybès aplinką.

Itampas stiprina ir integralumo stoka organizacijos veikloje. Komandos tikslai turètų būti derinami su organizacijos tikslais, o jos veikla - su institucijos pasirinkta strategija, priimamais sprendimais, tačiau praktiškai tai nevyksta. Laikantis naujo psichosocialinio sveikatos priežiūros požiūrio, ne tik darbuotojai, bet ir pacientas / klientas bei jo artimieji turètų dalyvauti gydymo ir psichosocialinès pagalbos procese, tapti aktyviais, visaverčiais komandos nariais. Tačiau praktika rodo, kad ir to nèra. 
Iš dalies struktūruoto interviu būdu surinkti duomenys analizuoti taikant interpretacijų metodą. Interviu su tyrimo dalyviais metu aptartos trys temos: vidinis požiūris ị komandą, socialinis darbuotojas komandoje, išorinis požiūris - komandos narių refleksija. Interviu rezultatų analizè ir interpretacija išryškino bendro tikslo ir bendradarbiavimo komandoje problemą. Ją lemia tai, kad komandinis darbas neorganizuojamas, tik keičiamasi informacija penkiaminučių metu, tai nepakankama komandos patirties aptarimo ir santykių komandoje formavimosi sąlyga.

[...] Jei atvirai, nėra tos komandos. Sprendžiu pagal tai, kad kiekvienas dirbam savo darbą. Sakyčiau, kad gana mažai bendradarbiaujam su užimtumo organizatore, socialine darbuotoja. Mūsų slaugytojos, tiesą sakant, ir nežino, ką veikia ta socialinė darbuotoja. Na, žino kažką abstrakčiai, ką ji turi daryti, o tokio ryšio tarp slaugytojų, gydytojų, užimtumo organizatorès, socialinès darbuotojos šiai dienai nèra. Galiu pasakyti tai tiesiai šviesiai ${ }^{1} \ldots$.. [V. K., 200709 10].

Teksto analizè atskleidè skirtingą komandos sudèties supratimą. I klausimą, kokių profesijų žmonès sudaro skyriaus komandą, visi tyrimo dalyviai atsakè skirtingai. Tai leidžia teigti, kad komandos, komandinio darbo sampratos praktiškai neaptariamos ir lieka nesuprastos. Dauguma tyrimo dalyvių kaip komandos narius vardijo tuos žmones, su kuriais tenka daugiausia bendradarbiauti, keistis informacija apie klientus / pacientus. Akivaizdu, kad praktinès veiklos lygmeniu stebimos komandos formavimosi prielaidos, tačiau organizacijos lygmeniu tikslingas komandos telkimo procesas nevyksta.

Tyrimo dalyviai socialiniam darbuotojui priskiria du - vykdytojo ir specialisto - vaidmenis komandoje. Pati socialinè darbuotoja suvokia save ir kaip išteklių tyrinėtoją. Galima sakyti, kad taip atsiskleidžia socialinès darbuotojos potencialumas. Visos tyrimo dalyvės pripažino, kad pagrindinis vaidmuo komandoje tenka gydytojui. Jos pabrèžè, kad santykiai skyriuje grindžiami hierarchiniu, subordinacijos principu. Šios aplinkybès nepalankios grupès ar komandos santykių formavimuisi:

[...] Aš manau, kad medicinoje yra labai ryški hierarchija, labai ryški. Iš tikrujų yra, kaip sakant, kas su baltu chalatu, tas - aukščiau. Tas jaučiasi. Iš tikrujų, pajausi, kad ir seselè praeis ir gali net nepasisveikinti su tavimi. Ir tai nebus dèl to, kad asmeniškai kažką blogo padarem... [G. B., 200709 17].

Tyrimas atskleide, kad socialinio darbuotojo pozicija skyriuje nèra tvirta. Tik viena iš tyrimo dalyvių pastebejo, kad gerai funkcionuojančioje komandoje yra daugiau galimybių reikštis socialinio darbuotojo ir užimtumo organizatoriaus vai-

Respondentų kalba netaisyta. 
dmenims. Dèl to laimi pacientas, nes geriau patenkinami jo poreikiai. Interviu su gydytojomis atskleide, kad socialinis darbuotojas suprantamas kaip savo srities specialistas, kuriam pripažistami tam tikri specifiniai vaidmenys. Tam tikrais etapais pacientui socialinio darbuotojo pagalba tampa svarbesnè už medikų. Toks komandos vadovo pripažinimas turètų stiprinti socialinès darbuotojos poziciją. Tačiau tai nepakankama sąlyga, nesant kolegų palaikymo. Tyrèjos, socialinio darbo studentès, refleksija atskleidè prieštarą tarp tyrèjos pasirengimo puoselèti santykius ir jos nepakankamo aktyvumo komandos veikloje. Interpretuojant tyrimo rezultatus galima teigti, kad saugios vienybès aplinkos kūrimo galimybès organizacijoje, kurioje atliktas tyrimas, nepakankamos. Tai tampa trukdžiu komandos formavimosi procese.

Socialinių darbuotojų paramos lūkesčiai, kaip bendradarbiavimo prielaida. Aukščiau aptarti tyrimo rezultatai skatina klausti, kaip bendradarbiavimą „,mato“ socialiniai darbuotojai, kokius lūkesčius su tuo sieja? Ar jie motyvuoti mokytis iš patirties, vieni iš kitų? Čia aktualios mokymosi iš patirties teorijos, akcentuojančios refleksijos svarbą patirties kaupimo procese, taip tobulinant profesines kompetencijas (Jarvis ir kt. 2004; Kolb, 1984). Klausimų reikšmingumą patvirtina reprezentatyvaus kiekybinio tyrimo rezultatai, kurie atskleide nepakankamą bendradarbiavimą skirtingo tipo socialinių paslaugų organizacijose (Večkienė ir kt. 2007; Večkienė 2010). Pagrindžiant tyrimo metodologiją laikytasi nuostatos, kad praktinès patirties reflektavimas yra esminè profesinès kompetencijos tobulinimo sąlyga. Tačiau tai įmanoma saugioje socialinejje aplinkoje, esant kolegų palaikymui. Taigi praktikoje tikètinos prieštaros.

Šioje straipsnio dalyje aptariamų tyrimo rezultatų interpretacijai reikšminga M. Eraut (2004) įžvalga, kad planuojant paramą ir palaikymą tikslinga atsižvelgti ị trejopą sąveiką: pasitikèjimas, iššūkiai, palaikymas. Užtikrinant asmens palaikymą skatinamas pasitikèjimas savo galimybėmis, didèjantis pasitikèjimas ịgalina geriau veikti sudètingose situacijose, valdyti jų kaitą. Taip sukuriamas teigiamo vystymosi ciklas, lemiantis vienijančios aplinkos kūrimą, grindžiamą tarpdisciplininiu bendradarbiavimu. Parama straipsnyje suprantama trejopai: a) palaikanti parama - tai asmeniniais santykiais grindžiama parama, emocinis palaikymas komandoje, organizacijoje; b) pastiprinanti parama - grindžiama dalykiniais santykiais sprendimų priemimo procese, bendradarbiavimu su kolegomis ir vadovais, informacijos mainais, darbo aplinkos ypatumais; c) igalinanti parama - konsultantų, specialistu palydèjimas procese: supervizija (profesinių santykių konsultavimas); asmeninis konsultavimas arba terapija (psichologo pagalba); dvasinè pagalba.

Toliau pristatomi tyrimo duomenys atskleidžia socialinio darbo praktikų ir vadovų poziciją paramą teikiančio bendradarbiavimo atžvilgiu (Večkienė, Eidukevičiūtè, 2007). Tyrimo duomenys analizuojami laikantis nuostatos, kad pagrindiniai 
paramos šaltiniai yra socialiniai tinklai, kurie gali būti suprantami kaip sąsajų sistema, komunikacijos tinklas, socialinių ryšiu forma, individų taikoma strategija. Socialinis darbuotojas visada dalyvauja dviejų tipų dalykiniuose santykiuose: profesionalo ir vadovo, profesionalo ir profesionalo, tačiau kiekvienoje organizacijoje egzistuoja ir tarpasmeniniai santykiai, grindžiami emociniais bei dvasiniais ryšiais.

Tyrimo duomenims analizuoti ir interpretuoti taikant B. Gendron (2004) pasiūlytas emocinès kompetencijos bei emocinio kapitalo sampratas, galima skirti du esminius socialinio darbuotojo veiklos aspektus - emocinį ir pažintinị. Emocinio kapitalo samprata, kurią B. Gendron sieja su asmenine ir socialine kompetencija, leidžia pagrịsti reflektavimo svarbą ,perdegimo“ prevencijos procese. Apibendrinant ir ieškant sąsajų remtasi nuostata, kad emocinis kapitalas gali būti laikomas baziniu, plètojant žmogiškajji ir socialinį kapitalą (Coleman, 2005). Socialinị kapitalą suprantant kaip bendradarbiavimą, sukuriamos visa apimančio paramos supratimo prielaidos, kai susiejamas emocinis palaikymas ir bendradarbiavimu grịsta pastiprinanti parama. Igalinanti specialistų parama šiuo atveju svarbi, kaip sukurianti sąlygas ịvertinti paramos tipą ir ieškoti naujų paramos galimybių. Sąsajos su demografiniais duomenimis analizuojamos kaip paramos poreikių prielaidos.

Toliau tekste pristatomi tyrimo rezultatai, kurie atskleidžia socialinių darbuotojų ir vadovų bendradarbiavimo kompetenciją, taigi ir pasirengimą dalyvauti kuriant vienijančią aplinką.

Palaikančios emocinès paramos lūkesčiai. Užuojautos, pritarimo, išklausymo, bendravimo, laisvalaikio leidimo kartu socialiniai darbuotojai daugiausia tikisi iš šeimos narių ir draugų, šiek tiek mažiau - iš kolegų. Tai sietina su natūralaus socialinio tinklo ypatumais, artimaja žmogaus aplinka ir neformaliomis grupėmis, kaip pagrindiniais emocinio palaikymo šaltiniais. Palaikančios emocinès paramos lūkestis beveik nepriklauso nuo išsilavinimo ir būdingesnis didžiuosiuose Lietuvos miestuose dirbantiesiems nei kaimo seniūnijos socialiniams darbuotojams.

Vadovo emocinès palaikančios paramos poreikis mažiau išreikštas ir beveik vienodas tiek didžiuosiuose Lietuvos miestuose, tiek seniūnijoje, išskyrus apskrities centrus, kur jis dar silpniau išreikštas. Galima svarstyti, kokie veiksniai lemia šį reiškinį: autoritarinis kontroliuojantis vadovo elgesys ar darbuotojų nepasitikèjimas savimi? Tikslinga klausti, ar įmanoma formuoti komandą tokioje situacijoje? Vadovo palaikymas svarbus socialiniams darbuotojams, dirbantiems su sergančiaisiais užkrečiamomis ligomis, neigaliaisiais. Tai sietina su didele emocine įtampa, kai reikia sutelkti visą organizacijos emocinị kapitalą.

Pastiprinančios, žinojimą praplečiančios paramos lūkesčiai. Socialinių darbuotojų veikla siejama su dar viena bendradarbiavimo plotme - socialinio darbuotojo ir kliento santykiais. Bendradarbiavimas yra esminis minètos veiklos 
bruožas ir etinių dilemų šaltinis. Interpretuojant susitelkta ties esminiu profesinės veiklos proceso elementu - sprendimų prièmimu. Reikšminga, kad supratimo, priežasties paieškos, sprendimo suradimo ir skatinimo jo ieškoti, patarimo pirmiausia tikimasi iš šeimos ir tik tada - iš kolegų. Lūkesčiai dèl vadovo - tik ketvirtoje vietoje. Kaip ir palaikančios emocinès paramos atveju, mažiausia paramos tikimasi iš specialistų. Tai, kad socialiniai darbuotojai remiasi tik asmeniniais santykiais, byloja dalykinių santykių ir bendradarbiavimo raiškos problemas. Tikètina, kad organizacijose nesuvoktas ir neįsisąmonintas bendradarbiavimo reikšmingumas, nesiekiama jo puoselèti. Supervizija, kurios paskirtis - skatinti profesinių santykių pažinimą ir jų kokybès pokyčius, šiuo atveju būtų veiksmingas konsultavimo metodas. Tačiau supervizijos ar kito tipo konsultavimo poreikis silpnai išreikštas, kaip ir poreikis naudotis paramos šaltinių ivairove.

Tai neramina, nes socialiniai darbuotojai dirba su kompleksinemis sistemomis, todèl vadovo ir kolegų parama, kurios lūkestis tyrime silpnai išreikštas, gali lemti intervencijos procesą. Socialinis darbuotojas atsakingas už turinio ir santykių dermę intervencijos procese, dalyvauja kliento socialinio paramos tinklo atkūrimo, išsaugojimo ir plètros procesuose. Todèl santykiai su kolegomis ir kitų profesijų atstovais yra ne mažiau svarbūs. Silpnai išreikštas pastiprinančios paramos poreikis gali byloti profesionalumo stoką. Socialiniai darbuotojai atsakingi už santykius, kuriems dažnai būdinga ịtampa ir konfliktai. Jų psichosocialinė kompetencija, gebejjimas reflektuoti ir priimti paramą lemia esmini apsisprendimą: siekį atpažinti konflikto prigimtį. Tik tada konfliktas gali tapti pokyčio prielaida.

Igalinančios paramos lūkesčiai. Socialinio darbo samprata, vertybès, ịstatymai kinta. Kinta ir klientų grupès, ištekliai, organizacijos, veiklos tikslai, turinys, metodai, priemonès, reikalavimai, keliami socialinio darbo procesui ir rezultatams. Kita vertus, esminè socialinio darbo nuostata - tik pats žmogus nori keisti ir keičia savo gyvenimą. Todèl būtinas bendradarbiaujantis, iggalinantis, tvirtas, draugiškas, situacijos analize, stebejjimu, bendravimu ir pasitikèjimu pagrịstas santykis su klientu ir jo artimaja aplinka. Tokia sąveikos sistema sudaro socialinio darbuotojo ir kliento refleksijos galimybes: poreikių atpažinimas, problemų įvardijimas ir būdų, kaip jas spręsti, paieška. Tačiau siekiant užtikrinti sąveiką būtinas teigiamas ir profesionalus požiūris ị pagalbos teikimo galimybes. Taigi svarbus paties darbuotojo gebėjimas klausti kolegų, kitų specialistų ir priimti paramą, taip kurti pasitikèjimo erdvę.

Tuo tarpu tyrimas atskleide, kad šeimos, draugų ir kolegų igalinančios paramos poreikis labiau išreikštas nei supervizoriaus igalinančios paramos ir šiek tiek mažèja vyresnèse amžiaus grupėse. Pvz., dirbant su bedarbiais tikimasi draugų igalinančios paramos, nors kvalifikuotas konsultavimas šiuo atveju būtų daug efektyvesnis. İdomu, kad igalinančios paramos lūkestis ryškiausias didesniuose 
miestuose. Kyla klausimų dėl didesnio darbo intensyvumo ar socialinių darbuotojų kompetencijos skirtumų?

Menka motyvacija pasinaudoti igalinančia kitų profesionalu parama byloja bendradarbiavimo ir mokymosi iš patirties problemiškumą. Paradoksalu, tačiau igalinančios paramos poreikis, didejjantis, atsižvelgiant ị išsilavinimą, daug silpniau išreikštas nei šeimos paramos poreikis. Net magistro išsilavinimą turintys socialiniai darbuotojai daugiausia ịgalinančios paramos tikisi iš šeimos, tik tada iš kolegų. Tai gali būti siejama su didele emocine įtampa, kurią patiria socialiniai darbuotojai, šeima jiems svarbi visų pirma kaip emocinès palaikančios paramos šaltinis. Galima ir kita interpretacija - profesionali parama, konsultavimas vertinami nepakankamai. Supervizoriaus ir psichologo igalinančios paramos lūkestis išreikštas labai silpnai. Silpnas vadovo ir kunigo igalinančios paramos lūkestis stebimas dirbant su probleminėmis šeimomis ir vaikais, neigaliaisiais. Šiek tiek ryškesnis ịgalinančios paramos lūkestis tų socialinių darbuotojų, kurie labiau sieja teoriją ir praktiką.

Galima tikètis, kad vadovams ir socialinį darbą organizuojantiems darbuotojams igalinanti parama yra aktualesnè, nes atlikti vadovo vaidmeni įmanoma tik bendradarbiaujant. Tačiau vadovai nelinkę ieškoti profesionalios pagalbos. Todèl situacija gali tapti problemiška, nes profesionalios pagalbos ir konsultavimo galimybių paieška visų pirma priklauso nuo vadovo sprendimų. Tuo labiau, kad socialiniai darbuotojai vidinius ir išorinius paramos išteklius daugiausia sieja su šeimos ir kolegų emociniu palaikymu. Tai kelia klausimą apie asmeninių ir dalykinių santykių suvokimą ir racionalų išskyrimą profesinèje veikloje bei leidžia formuluoti ịžvalgą apie būtinybę plètoti socialinių darbuotojų bendradarbiavimo kompetenciją, siekiant adekvačios vaidmenų raiškos tarpdisciplininėse komandose.

\section{Edukacinès mokymosi bendradarbiauti prielaidos ir galimybės}

Šioje straipsnio dalyje, aptariant pirmają tarpdisciplininio bendradarbiavimo plètotès prielaidų grupę, laikomasi nuostatos, kad susitarimai dẻl bendros vizijos, tikslo ir vertybių lemia sẻkmingą kiekvieno profesionalo veikimą komandoje, kartu ir tarpdisciplininị bendradarbiavimą. Todèl susitarimas dèl specialistų ugdymo tikslų, suformuluotų remiantis bendromis vertybėmis, yra esminè bendradarbiavimo kompetencijos ugdymo sąlyga (Walter, Petr, 2000).

Tarpdisciplininio bendradarbiavimo prielaidos studijų programose. Siekiant nustatyti komandinio darbo prielaidas studijų procese, atlikta Lietuvos sveikatos mokslų universiteto medicinos ir slaugos bei Vytauto Didžiojo universiteto socialinio darbo studijų programų tikslų analizè. Analizuojant studijų programų tikslus, jų formuluotèse ieškota šias nuostatas apibūdinančių leksinių 
junginių, leidžiančiu išskirti komandinio darbo kompetenciją nusakančias kategorijas. Interpretuojant rezultatus remtasi ankstesniu tyrimu (Brunevičiūtė, Večkienè ir kt., 2004), kuris atskleidè sveikatos priežiūros specialistų ir socialinių darbuotojų profesinių kultūrų skirtumus.

Sveikatos priežiūros specialistų ir socialinių darbuotojų rengimo programų tikslų analizè atskleidè tam tikrus dèsningumus. Medicinos ir slaugos studijų programose stebimas profesinis išskirtinumas, orientacija ị kompetencijų, būtinų profesinei veiklai, ugdymą. Socialinis darbas Lietuvoje yra nauja profesija, jos tapatumas tebesiformuoja. Todèl socialinio darbo studijų programoje numatomas plataus profilio specialistų, gebančių integruoti skirtingus požiūrius, gebèjimus ir net skirtingas profesines kultūras, rengimas. Minèti skirtumai skatina derinti studijų tikslus. Siekiant išryškinti šio derinimo kryptis, atlikta studijų tikslų turinio (content) analizè, išskirtos bendros tikslų kategorijos.

Interpretuojant analizès rezultatus išryškèjo, kad visus atrinktus medicinos ir slaugos programų tikslus galima suskirstyti ị tris grupes, atsižvelgiant ị jų ugdomąją orientaciją, kompetencijos sritis ir jų realizavimo lygị. Didžiausią grupę sudaro tikslai, nukreipti ị komandinị darbą, komandos narius, bendradarbiavimą. Tikslai akcentuoja kompetencijos žinių sriti. Antrą grupę sudaro tikslai, kreipiantys ị asmenybės elgsenos savybes, tarpasmeninių santykių supratimą, problemų identifikavimą, analizę ir savianalizę. Šie tikslai akcentuoja kompetencijos vertybių sritį. Trečia ir dvigubai mažesnè tikslų grupè kreipia ị sẻkmingą bendravimą. Šie tikslai akcentuoja kompetencijos ịgūdžių sritị.

Socialinio darbo pagrindinių ir magistro studijų programose tam tikri sveikatos klausimai integruoti ị daugelị modulių. Pasirenkamieji dalykai skiriami specifinèms socialinio darbo sritims pažinti, tarp jų yra ir specialūs moduliai, skirti socialiniam darbui sveikatos priežiūros sistemoje, psichikos sveikatos ir gerontologijos studijoms. Socialinio darbo studijų programos modulių tikslai, atsižvelgiant ị jų ugdomają orientaciją, kompetencijos sritis ir šios kompetencijos realizavimo lygi, gali būti suskirstyti į keturias grupes. Didžiausią grupę sudaro tikslai, nukreipti ị bendradarbiavimą su individu, akcentuojant konkrečius santykio užmezgimo, palaikymo ir užbaigimo ịgūdžius bei vertybines dilemas. Antrą grupę sudaro tikslai, nukreipti ị žinias apie santykius grupėse - daugiausia šeimoje, taip pat kitose socialinèse grupèse, tačiau tikslų, orientuotų ị bendradarbiavimo kompetencijos komandoje igijimą, aptikta labai mažai. Trečią grupę sudaro tikslai, nukreipti ị bendravimo ir bendradarbiavimo tipo bei jo konteksto pažinimą, akcentuojant teorinių požiūrių ir vertybių svarbą. Ketvirtos grupès tik dviejų modulių tikslai nukreipti ì socialinị darbą sveikatos priežiūros sistemoje, akcentuojant veiklos ypatumus.

Apibendrinus medicinos, slaugos ir socialinio darbo studijų tikslų analizès rezultatus išryškejjo, kad programose didžiausias dèmesys skiriamas individualaus 
bendravimo kompetencijai. Bendravimas grupeje ir / ar komandoje aptariamas žinių lygmeniu. Nedaug dèmesio skiriama bendrauti organizacijos ar organizacijų tinklo lygmeniu. Visgi analizė leidžia teigti, kad sveikatos ir socialinio darbo specialistų rengimo programų tiksluose atsiranda pokyčių, leidžiančių kalbèti apie socialinės kompetencijos ugdymą. Šie tikslai sveikatos specialistų rengimo programose akcentuoja teorines žinias ir interpersonalinị realizavimą, socialinių darbuotojų rengimo programose - praktinę veiklą. Visose trijose programose pasigendama konkrečios orientacijos ị komandinị darbą. Perspektyviausias visų trijų programų bruožas yra vertybinė orientacija, pagalbos žmogui perspektyva.

Edukacinès mokymosi bendradarbiauti galimybès. Pagalbos žmogui perspektyvos raiška medicinos ir socialinio darbo studijų programose užtikrina tarpdisciplininio bendradarbiavimo plètotès galimybes. Ši perspektyva lemia kasdienès medikų ir socialinių darbuotojų veiklos strategiją, laiduojančią tarpdisciplininio bendradarbiavimo kompetencijos igijimą. Tikslingai ir sąmoningai ją realizuojant profesinejje veikloje tikètinas esminis pokytis vienijančios aplinkos kūrimo ir palaikymo procese.

Minèto proceso inicijavimo ir igyvendinimo galimybės sietinos, pirma, su socialinio darbo, kaip profesinès veiklos, interdisciplinine bei empirine prigimtimi, šiai veiklai būdingu kompleksiškumu, neapibrèžtumu, nebaigtinumu. Antra, socialiniai darbuotojai Lietuvoje pastaraisiais metais jau yra sukaupę supervizijos (profesinių santykių konsultavimo), taigi ir patirtinio mokymosi, grindžiamo reflektavimu, patirti.

Profesinių santykių konsultavimo patirties analizè atskleidžia asmeninès, socialinès ir profesinès kompetencijos sąsajų būtinybę ir efektyvumą pagalbos žmogui procese, užtikrina rezultatyvių darbuotojo ir kliento santykių palaikymą. Reflektuojant ir apibendrinant šių sąsajų raišką konkrečiame intervencijos procese, dalyvaujant supervizijos (profesinių santykių konsultavimo) procese gali būti konstruojamos naujos profesinès žinios, ịgalinančios motyvuotą dalyvavimą plètojant vienijančia aplinka.

Medikų veiklos kaita, kai gydymo procese vis dažniau akcentuojamos psichologinès ir socialinès sveikatos problemų sprendimo funkcijos, sukuria naujas tarpdisciplininio bendradarbiavimo galimybes. Probleminès situacijos, kurioms spręsti nepakanka ị biomediciną orientuotų kompetencijų, keičia požiūrị ị medikų veiklą ir lemia nuolatinès kompetencijos plètotès poreikị. Esminè naujovè šiame kontekste yra problemų sprendimu pagrịsto mokymosi (ang. Problem based learning) igyvendinimas Lietuvos sveikatos mokslų universitete.

Problemų sprendimu pagrịstas mokymasis, kaip edukacinè naujovė, leidžia kurti mokymosi aplinką, kuri skatina studentų savarankišką mokymąsi ir mokymąsi bendradarbiaujant grupejje, sudaro galimybes igyti asmeninę ir socialinę 
kompetenciją. Antra, studijų organizavimo kaita išryškina dèstytojo tutoriaus vaidmens reikšmingumą studentų grupès mokymosi procese. Taigi medikų profesinės veiklos kaita lemia ugdymo proceso kaitą universitete, skatina ugdymo dalyvių studentų ir dèstytojų - bendradarbiavimo kompetencijų plètotę.

Kaita socialinio darbo, medicinos ir ugdymo srityse lemia naujas tarpdisciplininès profesionalų komunikacijos galimybes. Skirtingų sričių profesionalų bendradarbiavimas tampa įdomiu procesu, kai įmanoma tikslingai kurti vienijančia aplinka, kuri užtikrina palankią ịgalinančią aplinką tiek klientui / pacientui, tiek pagalbos teikejjui. Mokymasis ir praktinè veikla tokioje aplinkoje, kurioje dominuoja palaikantys, pastiprinantys žmonių tarpusavio santykiai, didina pasitikejjimą, skatina dalyvauti, klausti ir priimti pagalbą.

Kaitos kontekste svarbus mokymosi organizavimo būdų ir metodų inovatyvumas tiek aukštojoje mokykloje, tiek praktikoje. Realizuojant savarankiško tęstinio studentų ir praktikų mokymosi nuostatą kinta formaliojo ir neformaliojo mokymosi turinys, stimuliuojama šio proceso dalyvių motyvacija bendradarbiauti. Straipsnio autorių pastarųjų metų stebejjimai socialinio darbo ir sveikatos specialistų rengimo srityje leidžia teigti apie tutoriaus ir supervizoriaus kompetencijos aktualumą ugdymo kaitos procese, kai mokymo procesą keičia mokymosi procesas.

\section{Išvados}

1. Tyrimų apžvalgos rezultatai ir jų interpretacija išryškino tris konceptualias sampratas, reikšmingas tarpdisciplininès komunikacijos ir bendradarbiavimo požiūriu: multikultūriškuma, multiraštinguma, socialinị kapitala. Globalizacijos nulemtų socialinių ịtampų kontekste šios sampratos gali būti suprantamos kaip svarbiausias igalinančios vienijančios aplinkos kūrimo išteklius, senejjančioje visuomenėje reikšmingai papildantis ekonominị ir žmogiškajị kapitalą:

- Multikultūriškumas, kaip esminis šiuolaikinès visuomenès bruožas, patvirtina tarpkultūrinès ir tarpdisciplininès komunikacijos svarbą, skatinant bei palaikant asmens saviraišką ir dalyvavimą vienybés aplinkos kūrimo procesuose, kai dominuojančios ekonominès, politinès ar socialinès jègos ardo bendruomenes, žmonių sveikata ir gerovè nyksta dèl nelygybės ir nestabilios aplinkos.

- Multiraštingumo samprata atliepia XXI amžiaus žmogui keliamus reikalavimus, užtikrina dalyvavimą ir atsakomybę už savo veiklos padarinius, siejama su informacijos paieškos bei naudojimo gebẻjimais ịvairiose kintančio socialinio gyvenimo srityse. Kita vertus, multiraštingumo tema išryškina ịtampas tarp asmens raštingumo ir paslaugas teikiančių 
darbuotojų bei organizacijos ar bendruomenès raštingumo. Šios įtampos tampa esminès senejjimo ar negalès atveju.

- Socialinio kapitalo samprata tampa esmine, laikantis nuostatos, kad senejjimas ir negalia nèra galimybių nebuvimas, įmanoma nepriklausomybẻ ir savarankiškumas, užtikrinus tam tinkamas sąlygas. Tokios sąlygos gali būti kuriamos, ịgyvendinant saugios fizinès ir psichosocialinès arba vienijančios aplinkos idèją. Tačiau siekiant ịgyvendinti šią idèją, būtina tarpdisciplininė komanda, kurios nariai palaikančio ir pastiprinančio bendradarbiavimo dèka užtikrina socialinio kapitalo, kaip esminio vienijančios aplinkos ištekliaus, kaupimą.

2. Apibendrinus tarpdisciplininio bendradarbiavimo tyrimų rezultatus išryškèjo pagrindinis susikalbèjimo tarpdisciplininèje komandoje barjeras - skirtingi požiūriai, neleidžiantys sveikatos specialistams ir socialiniams darbuotojams atrasti tų bendrujų vertybinių pozicijų, kurios vienytų jų veiklą. Bendradarbiavimo trukdžius lemia ir nepakankamas paramą teikiančio bendradarbiavimo svarbos suvokimas. Skirtingos žinios ir metodai, nulemti skirtingos profesinès veiklos paskirties bei patirties, taip pat gali tapti susikalbejjimo barjeru. Kaip rodo tyrimų rezultatai, barjerų ịveikimo laidas gali būti socialinio darbuotojo pastangos ieškoti susikalbèjimo galimybiu ir ryškejjantis sveikatos specialistų supratimas apie socialinio darbuotojo vaidmenị.

3. Studijų programų analizès rezultatai atskleidžia mokymosi dirbti komandoje prielaidas, galima teigti, kad visų trijų profesijų (gydytojų, slaugytojų, socialinių darbuotojų) rengimo programose koreguojant ugdymo tikslus, gali būti kuriamos tyrimų metu išryškejjusių tarpdisciplininio bendradarbiavimo problemų sprendimo prielaidos. „Centre - studentas“ nuostatos igyvendinimas iš esmès keičia studento ir dėstytojo elgseną bei jų santykius. Tai geriausiai pasireiškia problemų sprendimu grindžiamo mokymosi procese, kuris užtikrina galimybes tobulinti bendradarbiavimo kompetenciją.

Siekiant užtikrinti studentų savarankiškumą, jie skatinami prisiimti atsakomybę už mokymosi tikslus, procesą ir rezultatą. Straipsnyje aptariamų tyrimų rezultatai leidžia teigti apie dvejopo konsultavimo reikšmingumą. Pirma, konsultavimas, kaip tutoriaus palydejimas mokymosi procese, antra, supervizoriaus, kaip profesinių santykių konsultanto palydejjimas praktikos procese. Vienijančios aplinkos palaikymo prasme svarbu tai, kad konsultantas tiesiogiai nedalyvauja problemos nustatymo, sprendimo paieškos, projektavimo veikloje. Dėstytojas tutorius atsako už mokymosi kryptingumą, nuoseklumą, rezultatyvumą ir ịsivertinimą, supervizorius - už patirties reflektavimą ir profesinès kompetencijos tobulinimo tikslų numatymą. 


\section{TARPDISCIPLININIS BENDRADARBIAVIMAS KURIANT VIENIJANČIĄ APLINKĄ}

\section{Literatūra}

Abstract book. (2012). Joint World Conference on Social Work and Social Development. Action and Impact. 8-12 July 2012, p. 435. Stockholm, Sweden.

Bell, D. (2003). Kapitalizmo kultūriniai prieštaravimai. Vilnius: Alma littera.

Bogdanova, J., Večkienė, N. P. (2009). Partnerystė rengiant socialinius darbuotojus: tarpdisciplininės komandos patirtis psichiatrijos skyriuje. Socialinis darbas. Patirtis ir metodai, Nr. 3 (1), p. 19-35. Kaunas:Vytauto Didžiojo universitetas.

Bourdieu, P. (1994). Language and Symbolic Power. Cambridge, Oxford.

Brunevičiūtė, R., Braždžionytė, J., Gudaitytė, D.,Večkienė, N. P. (2007). The Influence of Educational Research on Changes in the Content of Studies: a Comparative Study of the Curricula of Medicine and Social Work. Genth. Prieiga internete: http://www.education-line@leeds.ac.uk.

Brunevičiūtè, R., Večkienè, N. P. ir kt. (2011). Practical preconditions for the development of the interdisciplinary collaboration competence in healthcare. Santalka: filolologija, edukologija, Nr. 2, p. 132-140. Vilnius: Technika.

Brunevičiūtè, R., Večkienė, N. P., Naujanienė, R., Braždžionytė, J. (2005). Intercultural dimension within the changes in the aims of the curriculum. Dublin. Prieiga internete: http://www.education-line@leeds.ac.uk.

Coleman, J. S. (2005). Socialinès teorijos pagrindai. Vilnius: Margi raštai.

Eidukevičiūtè, J. (2013). Family Social Work Practices in the Context of Transitional Lithuanian Society. Acta Universitatis Lapponiensis 250. Lapin yliopistokustannus: Rovaniemi.

Eraut, M. (2004). Deconstructing Apprenticeship Learning: what factors affect it quality? New Approaches to Vocational Education in Europe. The construction of complex learning-teaching arrangements. Oxford Studies in Comaparative Education, p. 45-57.

Foucalt, M. (2001). The Order of Things: An Archaeology of the Human Sciences. Routledge, London.

Gendron, B. (2004). Why Emotional Capital Matters in Education and in Labour? Toward an Optimal Exploatation of Human Capital and Knowledge Management. Les Cahiers de la Maison des Sciences Economiques, serie rouge, Nr. 113, p. 35. Paris: Universite Pantheon - Sorbonne.

Jarvis, P., Holford, J., Griffin, C. (2004). The Theory and Practice of Learning. London: Kogan Page.

Kavaliauskienė, V. (2005). Socialinio darbo, kaip pagalbos žmogui profesijos, raidos aspektai. Acta Paedagogica Vilnensia. Mokslo darbai, T. 15. Vilniaus universiteto leidykla.

Kira, M., Van Eijnatten, F. M. (2009). Sustained by Work: Individual and Social Sustainability in Work Oorganizations. Creating Sustainable Work Systems. Routledge, London and New York, p. 233-247.

Kirikova, L. (2006). Modeling of the professional education and training of family physicians. Summary of doctoral dissertation: social sciences, education science (07 S). Vytautas Magnus University. Kaunas.

Kolb, D. A. (1984). Experiential Learning. Experience as the Source of Learning and Development. Englewood Cliffs, New Jersey: Prentice-Hall.

Lorenz, W. (1998). Social Professions for a Social Europe - European Dimensions in Training and practice of Social Professions. Ostrava: University of Ostrava.

Payne, M. (2015). Modern social work theory. Oxford University Press.

Tomlinson, J. (2000). Globalization and Culture. Polity Press in Association with Blackwell Publishers.

Urponen, K. (2017). Current Social Work Imposes New Challenges: Two Approaches And A Paradigm Shift. Tiltai. Mokslo darbai, Nr. 77 (2), p. 1-10.

Večkienė, N. P. (2010). Supervizija socialiniame darbe: paramą teikiantis bendradarbiavimas. Socialinis darbas. Patirtis ir metodai, Nr. 6(2), p. 119-134. Kaunas: VDU.

Večkienė, N. P., Budejjienè, A., Ražanauskaitė, V., Ramanauskienė, K., Valiulis, A. (2012). Socialinis darbas senejjančioje visuomenèje: teoriniai ir praktiniai tarpdisciplininio bendradarbiavimo aspektai. Gerontologija, Nr. 13 (1), p. 3-11.

Večkienė, N. P., Budejjienè, A., Ražanauskaitè, V., Ramanauskienė, K., Valiulis, A. (2012). Socialinis darbas senėjančioje visuomenėje: teoriniai ir praktiniai tarpdisciplininio bendradarbiavimo aspektai. Gerontologija, Nr. 13(1), p. 3-11.

Večkienė, N. P., Dirgèlienè, I. (2009). Streso rizika ir paramos lūkesčiai: socialinių darbuotojų profesinės patirties analizè. Tiltai. Mokslo darbai, Nr. 1 (46), p. 143-159. Klaipėda: KU.

Večkienė, N. P., Dirgèlienė, I. (2010). Paramą teikiantis bendradarbiavimas socialinio darbo procese: nuo idejjos link praktikos. Socialinis ugdymas, Nr. 11(22), p. 35-43. 
Večkienè, N. P., Eidukevičiūtè, J. (2016). Komunikacinès kompetencijos raiška profesinio identiteto paieškoje. Tiltai, Mokslo darbai, Nr. 3, p. 17-36.

Večkienè, N., Eidukevičiūtè, J. (2004). Interdisciplinary teams and transdisciplinary Networks for child and family Inclusion: The Relevance of European Theory to Lithuanian Practice. Parma University.

Večkienè, N., Eidukevičiūtè, J. (2009). Tutoriaus ir mentoriaus funkcijos socialinio darbo studentų mokomosios praktikos procese. Profesinis rengimas: tyrimai ir realijos, Nr. 17, p. 204-228.

Večkienė, N., Ruškus, J., Dirgèlienė, I., Kiaunytė, A., Kanišauskaitė, V. (2007). Supervizijos taikymo plètojant socialiniu darbuotoju profesines kompetencijas modelio parengimas. Tyrimo ataskaita. Vilnius: VMSF.

\title{
INTERDISCIPLINARY COLLABORATION FOR DEVELOPMENT UNITY ENVIRONMENT
}

\author{
Nijolė Petronėlė Večkienė, Raimonda Brunevičiūtė, Julija Eidukevičiūtė \\ Summary
}

The article presents the results of Vytautas Magnus University and Lithuanian University of Health Sciences teachers implemented continuing studies which justifies the importance of collaboration between social workers and other professionals working in the field of helping professions, creating a person's supportive social environment, which the article perceives as a unity environment. There are analyzed theoretical and empirical, aspects of cooperation between social workers, health professionals and educators, emphasizing the conceptual attitude of personal empowerment and its significance in an aging, transforming society. The interpretation of the research based on qualitative research methodology results revealed, the interdisciplinary cooperation in practice is discussed, the changes of professional training and continuing education are highlighted, emphasizing readiness to work in an interdisciplinary team. In the first part of the article there are discussed social tensions, their expression in social work and healthcare practice, revealing the challenges for a person - a professional and a client. The second part of the article highlights the interdisciplinary communication, leading to the creation of enabling environment of unity, and the importance of social tensions in the context of supportive cooperation discussed resolution it's practice. In the third part there are analyzed cases for the conditions and possibilities of educational interdisciplinary cooperation: the results of the analysis of medical and social work study programs are reflected; introduced changes in the organization of study programs, discussed the expression of innovations in study programs and practice. There is emphasized counseling as a key factor in educational change in the implementation of a "learner center", a lifelong learning strategy in the process of continuing education. In formal professional training, this can ensure the position 
of the tutor, empowering systematic studying; in practice, supervisor encouraging reflection on professional experience, thus developing competence.

The results of the survey review and their interpretation have highlighted three conceptual concepts, significant interdisciplinary communication and cooperation understanding: multiculturalism, multi-literacy, social capital. Globalization stipulates social tensions, in this context of these understandings can be perceived as a key empowering environment for the unity of the resource, in an aging society significantly complementing the economic and human capital.

Multiculturalism as an essential feature of modern society confirms the importance of intercultural and interdisciplinary communication by promoting and sustaining individual self-expression and participation in the process of creating a unity of environment where dominant economic, political or social forces frustrate communities and people's health and well-being disappear due to inequalities and unstable environments.

The concept of multi-literacy meets the requirements of the 21 st century for a person, ensures participation and responsibility for the effects of its activities and is linked to the ability to find and use information in various areas of a changing social life. On the other hand, the topic of multi-literacy highlights tensions between personality literacy and service providers and organization or community literacy. These tensions become essential in the cases of aging or inability.

The concept of social capital is essential, in accordance with the provisions of that aging and disability is not lack of opportunity, it is possible independence and autonomy to ensure proper conditions. Such conditions can be created by implementing the idea of creating a safe physical and psychosocial environment or a unity environment. However, in order to realize this idea, an interdisciplinary team is required, the cooperation of its members is conditional on the development of social capital.

Summarizing the results of interdisciplinary collaborative research, the main interfacing interdisciplinary team barrier was revealed - different attitudes that prevent health professionals and social workers from discovering common values that unite their activities. Barrierrs for cooperation are also conditioned by insufficient understanding of the importance of supporting cooperation. Different knowledge and methods due to the purpose and experience of different professional activities can also become a communication barrier. Research shows that the social worker's efforts to seek out communication opportunities and the growing awareness of the role of a social worker in health professionals can be a precondition for overcoming barriers.

The results of the study program analysis reveal the preconditions for learning to work in a team - it can be stated that adjusting education objectives in all three 
occupations (doctors, nurses, social workers) may create preconditions for solving interdisciplinary cooperation problems that have emerged in the research. The idea of "Student Center" essentially changes the behavior of the student and the teacher. This is most vividly manifested problem solving-based learning, including through studies, project approach and practice. This creates opportunities for the development of cooperation competence.

In order to ensure students' autonomy, they are given "responsibility" for learning goals, processes and outcomes. The results of the research in the article make it possible to state the significance of dual counseling. First, counseling on how to accompany a tutor in the learning process; second, attending a supervisor as a professional counselor in the practice process. In the sense of maintaining the unity of the environment, it is important that the consultant does not directly participate in problem solving, decision-making, designing activities. Teacher tutor is responsible for learning purposefulness, consistency, performance and self-evaluation, supervisor - for the purpose of reflection of experience and development of professional competence. 